\title{
DEVELOPMENT OF LEARNING DEVICES BASED ON DISCOVERY LEARNING MODEL ON GLOBAL WARMING TOPIC TO IMPROVE STUDENT LEARNING MOTIVATION AND LEARNING OUTCOME
}

\author{
Mega Safana, Muhammad Zuhdi, and Jannatin 'Ardhuha \\ Physics Education Department, FTTE, University of Mataram, Mataram, Indonesia \\ *Email: megasfn14@gmail.com
}

Acceped: August 27 2021. Approved: Sept 02 2021. Published: Sept 042021

\begin{abstract}
This study aims to develop learning devices based on a discovery learning model on global warming topics that are feasible to improve student physics learning motivation and outcome. The research is a research and development study with the ADDIE model standing for Analyze, Design, Development, Implement, and Evaluate. The developed research instruments are syllabus, Lesson Plan (LP), Student Worksheet (SW), learning video, and test instrument. Meanwhile, data collection instruments include a validation sheet, motivation questionnaire, along pre-test and post-test sheets. Paired sample T-test was used to assess the comparative hypothesis of the two samples' average. The research instruments were developed at the Department of Physics Education Laboratory, Faculty of Teacher Training and Education, University of Mataram and applied in XI MIA 1 class of State Madrasah Aliyah 1 Mataram. Those instruments were syllabus, LP, SW, and test instruments. The developed learning devices based on the discovery learning model were assessed by three expert validators, physics lecturers, resulting in learning devices with "very good" criteria. Hence, the learning devices based on the discovery learning model were feasible to be applied to improve student physics learning motivation and outcome. Based on the implementation of learning devices at State Madrasah Aliyah 1 Mataram, student physics learning motivation was increased by 0.53 . In contrast, student physics learning outcome on global warming was improved by 0.47 ; therefore, both were categorized as "medium". According to paired sample t-test using SPSS 22, the physics learning outcome was $0.000<0.005$ indicating a significant difference between before and after the learning treatment on students.
\end{abstract}

Keywords: Discovery Learning, Learning Devices, Research and Development, ADDIE, Learning Motivation and Outcome

\section{INTRODUCTION}

Physics is a science studying natural phenomena or events and all interactions that occur in them. Physics is one of the branches of natural science consisting of concepts, principles, theories, and laws related to existing natural phenomena [1]. According to those processes, the proper methods and models are required for solving the problem to transfer the knowledge easily to high school students.

In the 21st century, the competency framework emphasizes a learning process that guides students to be creative, innovative, thinking critically in solving problems, communicative and collaborative [2]. In general, the physics learning process is dominantly teacher-centered. Delivery of learning materials is solely about transferring the knowledge to students without checking for student understanding. This type of learning process is usually called one-way learning, in which students only pay attention and take notes during the lesson given by the teacher [3]. It causes many students to be passive.

Program for International Student Assessment (PISA) reported that Indonesia got 6th place from the bottom or 74th rank among 79 countries. This report indicated that Indonesia's score in 2018 declined compared to that in 2015 [4]. The decrease in the PISA score can be seen in Table 1 below.

Table 1. Comparison of PISA scores in 2015 and 2018

\begin{tabular}{ll}
\hline PISA in 2015 & PISA in 2018 \\
\hline Reading ability: 397 & Reading ability: 371 \\
Mathematics ability: & Mathematics ability: \\
386 & 379 \\
Science ability: 403 & Science ability: 396 \\
\hline
\end{tabular}

Meanwhile, the survey on Trends in International Mathematics and Science Study (TIMSS) conducted by the Global Institute in 2015 revealed that Indonesia got 44th place out of 49 countries with an average score of 397 and was in the 4th lowest position in the field of science [5]. The data showed that students are less encouraged to develop learning motivation resulted in a low learning outcome.

Based on our observation at State Madrasah Aliyah 1 Mataram, the teacher applied a conventional learning model with the lecture or contextual teacher learning methods, resulting in students being less focused during the lesson. In addition, student motivation to learn physics was still low and therefore impacted the learning outcome. 
On the other hand, the limited space and time for learning during the pandemic caused the student motivation and learning outcome to be even more decreased. Since the teacher only assigned them to summarize the learning material and work on practice questions as a substitute for direct learning, students lacked understanding of the topic. It was highly inconvenient considering that the current learning material will be the basis for the future learning topic.

Based on these circumstances, different learning models and methods were needed, especially the more creative ones. Interesting learning devices were also required to facilitate the teacher during the learning process and improve learning motivation, and therefore increase the learning outcome. One of the suitable models is the discovery learning model. Discovery learning is a learning model which maximally involves student's whole abilities to seek and find things systematically, critically, logically, and analytically so that students can formulate their findings [6]. This learning model is very appropriate for the $21 \mathrm{st}-$ century learning process since it guides students to be active in learning.

\section{RESEARCH METHOD}

The research is a Research and Development type of research which is a research method used to develop specific products and assess the validity of those products [7]. The designed products in this study were learning devices on global warming topics for second-year high school students in the second semester. The model applied in this research was ADDIE (Analyze-DesignDevelopment-Implement-Evaluate) research model [8]. The ADDIE research model consists of 5 stages [7] which are depicted in the following figure.

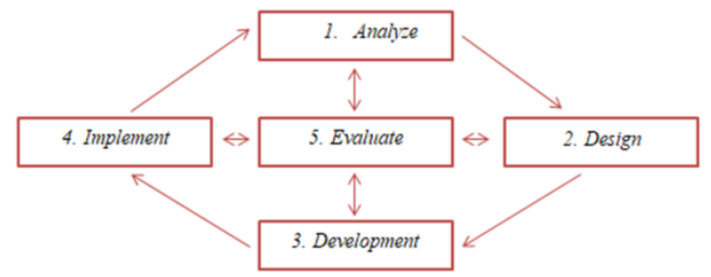

Figure 1. Development Stages Based on ADDIE Model

Source: According to Tegeh and Kirna (2013)

This development study was conducted at the Department of Physics Education Laboratory, Faculty of Teacher Training and Education, University of Mataram, and applied in XI MIA 1 class of State Madrasah Aliyah 1 Mataram. The research instruments used were learning devices consisting of the syllabus, Lesson Plan (LP), Student Worksheet (SW), learning video and test instrument, as well as data collection instruments comprised of validation sheet, learning motivation questionnaires, and post-test and pre-test sheets.

Three experts filled the validation sheet, physics lecturers at the Faculty of Teacher Training and Education, University of Mataram. Those experts could give scores in the validation sheet to choose one of the answers, as shown in Table 2.

Table 2. Research Instrument Score in Validation Sheet [9]

\begin{tabular}{ll}
\hline Answer Options & Score \\
\hline Very good & 4 \\
\hline Good & 3 \\
\hline Poor & 2 \\
\hline Very poor & 1 \\
\hline
\end{tabular}

The instrument had four answer choices, so the total score could be calculated using the following formula:

$$
\text { assessment score }=\frac{\text { total score of the instrument }}{\text { al of the highest score }} \times 4
$$

The conversion of the validation score of quality assessment by three expert validators can be seen in Table 3.

Table 3. Conversion of Assessment Scores into Category of Validity Score [9]

\begin{tabular}{ccc}
\hline $\begin{array}{c}\text { Assessment } \\
\text { Score }\end{array}$ & Average score & Category \\
\hline 4 & $3.26-4.00$ & Very good \\
\hline 3 & $2.51-3.25$ & Good \\
\hline 2 & $1.76-2.50$ & Poor \\
\hline 1 & $1.01-1.75$ & Very poor \\
\hline
\end{tabular}

The test used was paired sample t-test. The t-test is a statistical test allowing us to compare two average scores and determine the probability that the difference between two average scores is a fundamental difference and not a difference that occurs coincidentally [10]. Paired sample t-test was performed using SPSS 22.

According to Allo (2015) [11], the improvement of learning outcome can be determined using the Standard Gain with the following equation:

$$
N-\text { Gain }=\frac{\bar{X}_{\text {after }}-\bar{X}_{\text {before }}}{\bar{X}_{\text {max }}-\bar{X}_{\text {before }}}
$$

Note:

$\bar{X}_{\text {after }}$ : post-test score

$\bar{X}_{\text {before }}:$ pre-test score

$\bar{X}_{\max }$ : maximum score 100

Based on the Standard Gain calculation, student learning outcomes were categorized according to the interpretation in Table 4 . 
Table 4. N - Gain Index Interpretation [12]

\begin{tabular}{cc}
\hline$N-$ Gain Score $(\mathrm{g})$ & Category \\
\hline $0.70<\mathrm{g}<1.00$ & High \\
$0.30<\mathrm{g}<0.70$ & Middle \\
$0.0<\mathrm{g}<0.30$ & Low
\end{tabular}

Reliability in this study was assessed by the Borich method known as the Percentage Agreement (PA), which is the proportion of agreement between appraisers defined by comparing the scores between the first and second appraisers. Percentage Agreement (PA) can be formulated as follows.

$$
\text { Percentage Agreement (PA) }=\left(1-\frac{A-B}{A+B}\right) \times 100 \%
$$

Note:

PA: Instrument reliability (percentage agreement)

A: Score from an appraiser with higher score

B: Score from an appraiser with lower score

\section{RESULTS AND DISCUSSION}

The result of development using the ADDIE model standing for Analyze, Design, Development, Implement, and Evaluate will be elaborated. The analysis stage is an initial stage that aims to obtain information about the problems faced by teachers and students, problems that arise during learning, student characteristics, models used by teachers, learning media, and the applied curriculum. This stage includes learning requirement analysis and problem identification.

Requirement analysis was conducted to identify and determine the basic problems faced in physics learning by distributing observation sheets to students and interviewing the XI MIA 1 class of State Madrasah Aliyah 1 Mataram teacher. It was revealed that physics lesson was hard to be understood by the students resulting in low learning motivation and outcome. In addition, the students were often sleepy during lessons. Furthermore, the lack of learning media used to guide the students and attracted their attention in physics learning caused the lesson to be far from easy and attractive.

The design stage involves designing learning devices and a motivation questionnaire. The learning devices include the design of the learning scenario or the flow of the discovery learning model. The designed learning devices include syllabus, LP, SW, analysis of learning material, learning video, and test instruments. The competency-based physics syllabus was prepared based on competency, a set of abilities in the form of knowledge, skills, and attitudes that students can display or demonstrate because of physics learning [13]. The lesson plan (LP) describes the procedures and organization of learning to achieve a basic competency established in the content standards and elaborated in the syllabus, consisting of one or more indicators in one meeting [14]. Student Worksheet (SW) is a guide used to conduct investigation or problem solving [15]. The test instrument is a tool to collect information in the implementation of learning. It is also a collection of documents containing the learning scenario used by the teacher as a guide in the learning process [16].

The syllabus was designed as a reference for preparing a learning framework including Core Competencies (CC), Basic Competencies (BC), indicators of competency achievement, learning materials, learning activities, learning resources, and time allocation. The lesson plan (LP) was employed as a guide for teachers in conducting learning activities in the classroom so that the learning flow can be systematic and the delivery of material can be detailed and by the learning objectives that have been formulated. Student Worksheet (SW) contained questions designed with a discovery learning model approach that will guide students to make their discoveries based on the questions in $\mathrm{SW}$. This learning material analysis was designed to facilitate the teacher in delivering learning topics in the class. Analysis of learning material was made with various references of learning resources so that the analysis of learning materials can be valid and relevant. The test instrument was designed to measure learning achievement. In this case, the learning outcomes test instrument consisted of twenty multiple-choice items using reference questions, namely $\mathrm{C} 1, \mathrm{C} 2, \mathrm{C} 3$, and $\mathrm{C} 4$.

A test instrument is an assessment tool that we use to collect research data by implementing the learning devices [17]. It included the student motivation questionnaire, which contained twenty statement questions that can measure student motivation before and after learning. In addition to the motivation questionnaire, the design of the research instrument also involved a validation questionnaire which was used as an assessment to determine the feasibility of the developed learning devices. Validation was conducted by three expert lecturers of Physics Education at the University of Mataram. The validation questionnaire consisted of syllabus, LP, SW, and test instrument validation questionnaires.

The development stage is a stage for developing the product that has been designed. This stage included validation by three expert validators, physics education lecturers at the Faculty of Teacher Training and Education, University of Mataram, to evaluate the feasibility of implementing learning devices on students. The analysis of validation assessment accommodates the scores from expert validators as well as their suggestions and input.

The results of the validation assessment conducted by three lecturers of Physics Education, 
Faculty of Teacher Training and Education, Mataram University, are described in Table 5 below.

Table 5. Assessment Results of 3 Validators

\begin{tabular}{ccc}
\hline Learning Devices & $\begin{array}{c}\text { Average } \\
\text { Score }\end{array}$ & $\begin{array}{c}\text { Validation } \\
\text { Criteria }\end{array}$ \\
\hline Syllabus & 3.33 & Very Good \\
LP & 3.59 & Very Good \\
SW & 3.74 & Very Good \\
Test Instrument & 3.58 & Very Good \\
\hline
\end{tabular}

Moreover, comments and suggestions from the three validators on the syllabus were expected to improve the learning experience and media, upgrade the writing consistency, clarify lesson hours and minutes, along adjust learning activities. In the LP, learning objectives were added to achieve learning indicators. Attitude and performance assessments were not written in LP. SW in learning media was also not abbreviated. In addition, the consistency of learning resources, selection of appropriate words, suitability of the information in learning activities, and news delivered in each sub-chapter were wellconsidered. In SW, the scoring rubric was also thoroughly designed. Furthermore, in the test instrument, C4 level questions or those leading to analysis were added.

The next step was reliability analysis using the Borich method, namely the Percentage Agreement (PA), with the following results.

The instrument is categorized as reliable if the PA is more or equal to $75 \%$. If the percentage is less than $75 \%$, the instrument should be tested for clarity and approval by the observer [18].

The implementation stage of the learning devices was conducted in the XI MIA 1 class of State Madrasah Aliyah 1 Mataram to improve student motivation and learning outcomes. This stage responds to student motivation questionnaire data, pre-test score, implementation results on XI MIA 1 class of State Madrasah Aliyah 1 Mataram, post-test score, and learning devices distribution. Student motivation questionnaires were distributed to the XI MIA 1 class of State Madrasah Aliyah 1 Mataram. Only 25 respondents participated out of 39 students in the XI MIA 1 class of State Madrasah Aliyah 1 Mataram because the other 13 students did not have an adequate internet network. Response data were obtained from the response questionnaire with choices consisting of SA "Strongly Agree", A "Agree", N "Neutral", D "Disagree", SD "Strongly Disagree". The questionnaire was filled by marking $(\sqrt{ })$ on the answer choices. A likert scale with a range of 5 was employed in this study [19]. The responses to the student physics motivation questionnaire can be seen in Table 7 below.

The Gain Standard according to Allo (2015) [11] was applied using the following equation to determine the increase in student learning motivation:

$$
N-\text { Gain }=\frac{\bar{X}_{\text {after }}-\bar{X}_{\text {before }}}{\bar{X}_{\text {max }}-\bar{X}_{\text {before }}}
$$

Therefore,

$$
N-\text { Gain }=\frac{91,95-82,65}{100-82,65}=0,53
$$

Meanwhile, that for physics learning outcome is described in following Table 8:

Based on the table above, the normality test using SPSS 22 with Shapiro-Wilk showed the significance data normality of 0.017 (table 11). The table above exhibited the 2-tailed significance value of $0.000<0.005$ (table 12), indicating a significant difference between the pre-test and post-test. Therefore, there was a significant difference between before and after learning treatment to students.

\begin{tabular}{|c|c|c|c|c|c|}
\hline \multirow{2}{*}{ Product } & \multicolumn{3}{|c|}{ Validator PA Score } & \multirow{2}{*}{$\begin{array}{l}\text { Average Percentage } \\
\text { Agreement (PA) }(\%)\end{array}$} & \multirow[t]{2}{*}{ Category } \\
\hline & $\begin{array}{l}\text { V12 } \\
(\%)\end{array}$ & $\begin{array}{l}\text { V23 } \\
(\%)\end{array}$ & $\begin{array}{l}\text { V31 } \\
(\%)\end{array}$ & & \\
\hline Syllabus & 94.80 & 96.10 & 93.50 & 94.80 & Reliable \\
\hline LP & 93.87 & 89,79 & 89.79 & 91.15 & Reliable \\
\hline SW & 95.23 & 92.06 & 90.47 & 92.58 & Reliable \\
\hline $\begin{array}{l}\text { Learning } \\
\text { Video }\end{array}$ & 93.33 & 87.61 & 92.37 & 85.29 & Reliable \\
\hline $\begin{array}{l}\text { Test } \\
\text { Instrument }\end{array}$ & 91.06 & 94.64 & 89.28 & 91.66 & Reliable \\
\hline
\end{tabular}

Table 6. Reliability Analysis of Learning Devices 
Table 7. Results of Student Motivation Questionnaire

\begin{tabular}{ccc}
\hline Motivation & Total Score & Average Score \\
Questionnaire & 1653 & 82.85 \\
Pre-test & 1839 & 91.95 \\
Post-test &
\end{tabular}

Table 8. Student Physics Learning Outcome

\begin{tabular}{ccc}
\hline & Pre-test & Post-test \\
\hline Total Score & 1995 & 2500 \\
Average Score & 64.35 & 80.64 \\
Standard deviation & 9.72 & 5.73 \\
Variance & 94.47 & 32.83 \\
\hline
\end{tabular}

In addition, the result of the normality test using SPSS 22 is displayed in Table 11 below:

Table 11. Result of Normality Test

\begin{tabular}{ccc}
\hline \multicolumn{3}{c}{ Shapiro Wilk } \\
\hline Statistic & Df & Sig. \\
.915 & 31 & .017 \\
\hline
\end{tabular}

Table 12. Result of T Paired Sample Test

\begin{tabular}{|c|c|c|c|c|c|c|c|c|}
\hline & \multirow[b]{3}{*}{ Mean } & \multicolumn{4}{|c|}{ Paired Differences } & \multirow[t]{3}{*}{$\mathrm{t}$} & \multirow[t]{3}{*}{ df } & \multirow[t]{3}{*}{$\begin{array}{l}\text { Sig. } \\
(2- \\
\text { tailed })\end{array}$} \\
\hline & & \multirow{2}{*}{$\begin{array}{c}\text { Std. } \\
\text { Deviation }\end{array}$} & \multirow{2}{*}{$\begin{array}{l}\text { Std. } \\
\text { Error } \\
\text { Mean }\end{array}$} & \multicolumn{2}{|c|}{$\begin{array}{c}95 \% \text { Confidence } \\
\text { Interval of the } \\
\text { Difference }\end{array}$} & & & \\
\hline & & & & Lower & Upper & & & \\
\hline $\begin{array}{l}\text { PRE-TEST - } \\
\text { POST TEST }\end{array}$ & -16.29032 & 9.12576 & $\begin{array}{r}1.639 \\
04\end{array}$ & -19.63768 & -12.94297 & -9.939 & 30 & .000 \\
\hline
\end{tabular}

The increase in student learning outcome was calculated by the standard gain according to Allo using the following equation:

$$
N-\text { Gain }=\frac{\bar{X}_{\text {after }}-\bar{X}_{\text {before }}}{\bar{X}_{\text {max }}-\bar{X}_{\text {before }}}
$$

Therefore,

$$
N-\text { Gain }=\frac{80,64-64,35}{100-64,35}=0,45
$$

According to Sundayana (2014), 0.45 could be interpreted by the N-Gain index in the "medium" category. As a reference, a study on the effect of the discovery learning model on student physics learning motivation and outcome in State Madrasah Aliyah Bondowoso revealed that the discovery learning model indeed significantly affected student physics learning motivation and outcome in State Madrasah Aliyah Bondowoso [20].

The evaluation stage is a stage for activity evaluation aiming to revise each activity for the better. The evaluated stages include analysis, design, development, implementation, and evaluation stages. The analysis stage required strong analysis to analyze and conclude problems as well as offer the right solutions. At the design stage, accuracy was needed for choosing and adjusting the designs to the level of education to make them quickly understood and accepted by students. The development stage needed several checks that are useful to minimize errors and improve product accuracy and some input and evaluation to provide a better result. At the implementation stage, it was necessary to carefully design the online learning methods so that the online learning process could be more structured.

The implementation of the learning devices in XI MIA 1 class of State Madrasah Aliyah 1 Mataram faced several obstacles, including the lack of student response to motivation questionnaire and learning outcome assessment, including pre-test and post-test. Hence, some students refused to participate in answering questionnaires along with pre-test and post-test questions. In addition, online learning was conducted using WhatsApp (WA) groups instead of Google classroom or Zoom meetings since student response to WA groups was faster than the other media due to limited internet access. The limited internet access was also one of the main obstacles in learning. The students were required to answer questions and questionnaires in Google forms instead of WA group. Another obstacle was the lack of capability to control student activities during the online lesson, such as whether students have been involved in learning as instructed by the teacher. In addition, one of the designed methods was student presentation. It was not possible for the students to directly present the topic since the media was a chat group instead of a video presentation. The last obstacle was the fact that the designed learning devices were not online-based. Therefore, we needed to do a lot of spontaneous and quick improvisation during the implementation of 
learning devices. Thus, the implementation stage became less than optimal.

\section{CONCLUSION}

Based on the results and discussion, the developed learning devices based on the discovery learning model are categorized as "very good" and feasible to be implemented in learning and improve student physics learning motivation and outcome on global warming topics.

\section{REFERENCES}

[1] Helmi, F., Rokhmat, J., 'Ardhuha, J. (2017). Pengaruh Pendekatan Berpikir Kausalitik Berscaffolding Tipe 2b Termodifikasi Berbantuan Lks Terhadap Kemampuan Pemecahan Masalah Fluida Dinamis Siswa. Jurnal Pendidikan Fisika dan Teknologi.

[2] Hariyanto, Agus. (2016). Pengaruh Discovery Learning Berbantuan Paket Program Simulasi PhET Terhadap Prestasi Belajar Fisika. Jurnal Pendidikan dan Kebudayaan. Volume.1 No. 3.

[3] Ulfa, K., Buchori, A., dan Murtianto, Y. H. (2017). Efektifitas Model Guaided Discovery Learning Untuk Video Pembelajaran dalam Mengetahui Perbedaan Kemampuan Pemecahan Masalah Matematika Siswa. Journal of Mathematics Education, Science and Technology. Volume.2, December 2017. Page 267-275.

[4] Tohir, Muhammad. (2019). Hasil PISA Indonesia Tahun 2018 Turun dibandingkan Tahun 2015. Situbondo: Ibrahimy University.

[5] Hadi, Syamsul. (2019). TIMSS Indonesia (Trends in International Mathematics and Science Study). Proceedings of the National Seminar \& Call for Papers, Mathematics Education Master Study Program, Siliwangi University, Tasikmalaya, January 19th, 2019. ISBN: 978-602-9250-39-8.

[6] Lidiana. (2018). Pengaruh Model Discovery Learning Berbantuan Media Phet Terhadap Hasil Belajar Fisika Peserta Didik Kelas XI SMAN 1 Kediri Tahun Ajaran 2017/2018. Jurnal Pendidikan Fisika dan Teknologi, Volume 4 No.1.

[7] Sugiyono. (2012). Metode Penelitian Kuantitatif Kualitatif dan R\&D. Bandung: Alfabeta

[8] Tegeh, I.M., dan Kirna, I.M. (2013). Pengembangan Bahan Ajar Metode Penelitian
Pendidikan dengan ADDIE Model. Jurnal IKA. Vol 11 (1), 12-26.

[9] Suyanto, Eko dan Sartinem. (2009). Pengembangan Contoh Lembar Kerja Fisika Siswa dengan Latar Penuntasan Bekal Awal Ajar Tugas Studi Pustaka dan Keterampilan Proses untuk SMA Negeri 3 Bandar Lampung. Prosiding Seminar Nasional Pendidikan 2009. Bandar Lampung: Universitas Lampung.

[10] Setyosari, Punaji. (2013). Fourth edition Metode Penelitian Pendidikan dan Pengembangan. Jakarta: Prenada Media Grup.

[11] Allo, Tangke, A.T., Jatmiko, B., Agustini, R. (2015). Pengembangan Perangkat Pembelajaran Fisika Model Guided Discovery Learning Menggunakan Alat Sederhana untuk Mereduksi Miskonsepsi Siswa SMA pada Materi Fluida Statis. Jurnal Pendidikan Sains Pascasarjana Universitas Negeri Surabaya. ISSN: 2089-1776. Volume 5 No. 1.

[12] Sundayana, Rostina (2014). Statistika Penelitian Pendidikan. Bandung: Alfabeta.

[13] Mundilarto (2002). Kapita Selekta Pendidikan Fisika. Yogyakarta : FMIPA UNY.

[14] Syahidu, Hairunisah. (2018). Evaluasi Pembelajaran Fisika. Mataram: Arga Puji Press.

[15] Syahidu, C., Gunawan, Rokhmat, J., Rahayu, S. (2018). Pengembangan Perangkat Pembelajaran Fisika Berorientasi pada Kreativitas Calon Guru. Jurnal Pendidikan Fisika dan Teknologi. Volume 4 No.1.

[16] Sanjaya, Wina. (2010). Strategi Pembelajaran Berorientasi Standar Proses Pendidikan. Jakarta: Prenada Media Group.

[17] Irwan, S., Arsyad, M., Arafah, K. (2018). Pengembangan Instrumen Penilaian Sikap Praktikum FisikaDasar Pada Mahasiswa Jurusan Pendidikan Fisika UIN Alauddin Makasar. Jurnal Pendidikan Fisika dan Teknologi. Volume 4 No. 2.

[18] Borich, G. D. (1994). Observation Skill for Effective Teaching. New York: Machmillan Publishing Company.

[19] Sukardi. (2013). Metode Penelitian Kompetensi dan Praktiknya. Jakarta: Bumi Aksara.

[20] Putri, H. R., Lesmono, A. D., Aristya, P. D. (2017). Pengaruh Model Discovery Learning Terhadap Motivasi Belajar dan Hasil Belajar Fisika Siswa MAN Bondowoso. Jurnal Pembelajaran Fisika. Volume 6. No 2. 